\title{
MORRIS' SEMIOTIC IN RELIGION PERCEPTION AND CONCEPTION IN GANE OF POLINAKI TRADITIONAL WEDDING RITUAL IN KULAWI ETHNIC
}

\author{
Indah Lestari, Burhanuddin Arafah, Harlinah Sahib, Mustafa Makka \\ Faculty of Cultural Sciences, Hasanuddin University, Makassar, Indonesia) \\ E-mail: indahlestari@staff.gunadarma.ac.id
}

Received: 07 December 2020

Accepted: 19 December 2020

\begin{abstract}
The purpose of this research is to examine the concept of religion in Gane, a ritual speech which is still alive and practiced by Kulawi ethnic in Sigi regency, Central Sulawesi. Nowadays, Gane ritual speech is no longer in demand by most of the Kulawi ethnic, especially the educated young generation, because they have been eroded by the influence of modernization and globalization in addition to the influence of the entry of religion held by the majority of the Kulawi ethnic today and modern education. The text of Gane is obtained from a ritual speech named Polinaki which is contained in traditional wedding in Kulawi. The text is analyzed qualitatively using behavioral semiotic approach proposed by Charles Morris. Behavioral semiotic is creating a particular action or behavior to achieve a certain goal and applying syntactic, semantic, and pragmatic dimensions for analyzing a text. The results show that in syntactic dimension, Gane is a text with literary style consisting of unique characteristics in terms of structure, function, and meanings. In semantic dimension, Gane holds contextual, emotive, conative, and poetic meanings observed through its function. In pragmatic dimension, the impacts of Gane influence the perception and conception of religion.
\end{abstract}

Keyword: ritual speech, semiotics, traditional wedding, syntactic, semantic, pragmatic.

\section{Introduction}

Kulawi is a sub-district located in the district of Central Sulawesi. The Kulawi people still adhere to the old tradition which is inherited from their ancestors as guidelines for their daily life. Even though the people in Kulawi have embraced both Islam and Christianity, the people still practice the traditions of their ancestors' animistic beliefs in various events, such as life cycles ceremonies. In Kulawi, there are some forms of traditions performed and spoken in life ceremonies (Nitayadnya, 2014). One of the traditions is Gane, while the act of reciting Gane is called Nogane, while the speaker is called Topogane, Topobalia, or Hando.

Gane is included into ritual speech for it has different forms, meaning, and functions from ordinary speech (Sahib.H, Arafah, Manda, \& Machmoed, 2017). Nowadays, Gane ritual speech is no longer in demand by most of the ethnic Kulawi, especially the educated young generation, because they have been eroded by the influence of modernization and 
Morris' Semiotic in Religion Perception and Conception in Gane of Polinaki Traditional Wedding Ritual in Ethnic Kulawi, Indah Lestari, Burhanuddin Arafah, Harlinah Sahib, Mustafa Makka

globalization in addition to the influence of the entry of religion held by the majority of the ethnic Kulawi today and modern education.

The discussion of oral tradition of each nation's ancestral heritage is important for the educated young generation because if between each generation still shares transcendental value, surely individuals would have a foothold which is a basis of something new. In other words, if between young people and older generations share a good relationship of cultural devolution, then young people will have no problem finding their true identity. Moreover, there are so many benefits obtained by involving oral traditions in human life (Sahib, Rahman, Duli, \& Asba, 2019) and the meanings contained in rituals also provide value for people to behave (Ola, 2012).

On the contrary, the disconnection between generations will result the difficulty in determining their true self. Therefore, a discussion of the tradition as ancestral heritage is important for the educated young generation. This is a basic thought in preventing and promoting the tradition or a primary document whenever the ritual is not any longer performed within the future (Arafah, Thayyib, Kaharuddin, \& Sahib, 2020)

As an oral tradition belongs to Kulawi people, Gane is important to discuss for oral literature is a collective development and organization that uses language as a medium (Arafah, Jamulia, \& Kaharuddin. 2020). From it, we can learn the life of the people who own the tradition since this practice is established by the customs of the culture (Arafah \& Kaharuddin, 2019).

Therefore, the main problems examined in this study are the form and meaning contained in the Gane ritual speech, as one of the components in ritual of Polinaki, bridal bathing ritual in Kulawi, as well as their relationship with the religious perceptions of the people who use this ritual speech, especially in the Kulawi area. The people of Kulawi, especially the elders, still associates all disasters and misfortunes with errors in Gane reading process to rituals (based on an interview with an informant, Mr. Bakrie Jumbu). From that phenomenon, it caught the researcher's attention to see how people in Kulawi view religion and how Gane's role in building perception and conception of religion, as well as how their attitude towards Gane by examining the meaning contained in it.

\section{Literature Review}

According to Morris, 'semiotic as a science makes use of special signs to state facts about signs; it is a language to talk about signs' (Cherwitz, 2009). Departing from Peirce's semiotics on pragmatic semiotics (in Merrell, Queiroz., Merrell, \& Nadin, 2006) namely the concept of Firstness, Secondness and Thirdness and behaviorism theory developed by George H. Mead, Edward Tolman and Clark L. Hull (Petrilli 2004). Morris developed his own semiotics of semiotic behavior. In Morris's semiotic behavioral concept, a particular behavior is created to achieve a specific goal. By applying the semiotic concept of Peirce, Morris explained there are three semiotic components and one additional component, namely sign vehicle, referencing the concept of representamen of Peirce, designatum and denotatum, referencing the concept of objects from Peirce; interpreter; and interpretant, referencing the interpretant concept of Peirce (Rifa'in , S. B, Pa, M. T. Bin, \& Samah, 2018).

Morris gives an example of Pavlov training his dog by using a buzzer's sound as a sign that there is food for the dog. The semiosis here is Pavlov deliberately ringing a buzzer every time he gives food to his dog to instill an understanding in his dog that the buzzer is a sign that there is food for the dog. Previously, Morris also gave an explanation of preceding semiosis. Where in the above case, Pavlov's dog must be trained first to recognize and distinguish the 
buzzer from other sounds in order to be able to make the buzzer as his sign vehicle, (or representamen if we use the term by Peirce) In other words, to make a thing as a sign vehicle, there must be a preceding semiosis first. As a result, every buzzer is sounded, the dog will salivate as if that his dog is thinking about food. When following the concept of Peirce semiotics, Morris's behavioral semiotics concept can be described as follows by using an example from Pavlov's dog above.

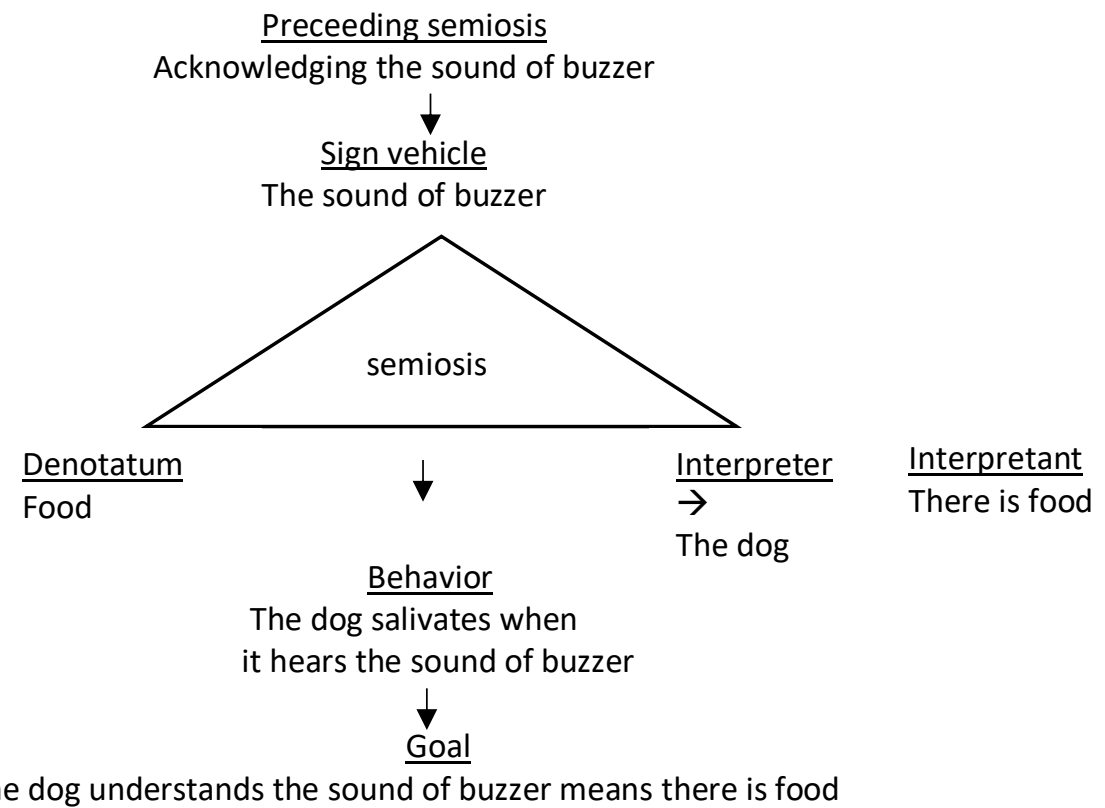

Picture 1. Depiction of Morris' semiotic

Later in his semiosis, Morris distinguishes three groups of semiotics in which the three are interconnected to obtain a true value, namely grammar, dialectic, and rhetoric which are similar to the concept of Peirce, grammar, critical logic, and methodeutic, which is distinguished into syntactic, semantic, and pragmatic dimension (Arafah \& Hasyim, 2019; Старцев et al., 2020). The dimensions of the syntax focus on the shape and function of the vehicle sign being discussed. The semantic dimensions focus on the classification and validity of the reference which is then divided into three parts namely the logic of abduction, induction and deduction. Finally, the pragmatic dimensions focus on the method, how the truth of a sign is achieved. Thus, semiotics is considered capable by researchers to see a value/role that exists in Gane in Kulawi society. As Petrilli (2004) stated "We may claim then that Morris's pragmatic conception of meaning led to his focus not only on signs but also on values.

Through the meaning of Gane as a form of religious communication, the view of religion of the community who owns it can be examined. Religion is a form of human thought about things that are in a different realm from the human realm, but has power and strength that exceeds human strength so that it is considered capable of having an impact on humans. The origin of religion is human awareness of the concept of spirit. This opinion is caused by two things, one of which is the obvious difference between living things and inanimate objects. The living things move, while the dead ones do not. By this notion, human begins to gain knowledge that the thing inside the living which has the force to move the body of the living, and it is the soul or spirit. 
Morris' Semiotic in Religion Perception and Conception in Gane of Polinaki Traditional Wedding Ritual in Ethnic Kulawi, Indah Lestari, Burhanuddin Arafah, Harlinah Sahib, Mustafa Makka

\section{Method}

This type of research is a qualitative one. The researchers are the key instruments in describing all existing data and are understanding based on methodologies that investigate social phenomena and human problems (Lewis, 2015). In this approach, researchers created a complex picture, examined words, detailed reports from the respondent's view, and conducted studies on natural situations.

\subsection{Source of Data and Data}

The type of data used in this study consists of primary data and secondary data. Primary data is data from field research results concerning the ritual speech obtained through the traditional wedding ceremony of Kulawi citizen namely Nisa and Yusuf on August 28, 2016, at the time of this research implemented and eight informants selected according to the ideal criteria required who represent Kulawi community.

The research data on the focus is the signs from Gane both verbal or non-verbal in the form of video recordings, audio visuals and oral data, the results of interviews from key informants and comparison informants. The verbal sign is the text of Gane. Non-verbal sign is the condition of the participants who are the Topogane, the groom, namely Yusuf and the bride, namely Nisa, and the event which is the ritual of Polinaki, when the groom and the bride was conducting bridal bath in a local river.

\subsection{Data Collecting Method}

In collecting the data, some techniques are used in this research to obtain more in-depth information, namely participatory observation and in-depth interview with open questions to the participants and random citizen of Kulawi to obtain information about oral stories, collective perception of Gane, and about their feelings and opinion regarding religion as also conducted by Akhmar, Arafah, \& Pardiman (2017).

This research also applied documentation study technique in the form of data collection which is available in various media, both print and electronic media. It is aimed at obtaining secondary data that is considered relevant to the character of the problems examined in this study.

\subsection{Data Analysis Method}

The data were analyzed qualitatively-analytically with the main data coverage which included Gane's ritual speech and contextual relationship with the overall ethnic Kulawi's religious perspective. Data were analyzed inductively in order to establish clear connection between the research objectives and the summary findings derived from the data (Thomas, 2006). The steps are starting from 1) data selection including the type of speech, topic, purpose and function, participants, the form and content of the message, the sequence of actions, the rules of interaction, and the norms of interpretation, data transcription, data corpus selection, translation, data analysis, and reports; 2 ) data transcription to textualize the oral data; 3 ) translation by using word for word then free translation; 4) data analysis, and 5) reports.

\section{Results and Discussion}

The results showed that religion is the most important dimension in Gane. The religion perspectives related to the ethnic Kulawi are the conceptualizations of the existence of God, ancestral spirits, and natural spirits, in relation to their existence as humans and members of society. These three supernatural powers are understood by the Kulawi ethnic group as the 
main source of moral strength that greatly determines their existence, survival and continuity as humans and members of society in the world and the hereafter. In accordance with the conceptualization, the details of the aspects of religion contained in Gane can be seen as follows.

Polinaki is a procession of bridal bathing the groom and the bride on the day before the ceremonial day of the wedding. This ritual is still carried out in Kulawi society. In Polinaki, there is a ritual speech spoken called Gane. The Gane can be seen as follow

(P-1) Karampu e mata eo, karampu e mata wula

Ruler sun ruler moon

The lord of sun, the lord of moon

(P-2) Kunuju I Yusuf, I Nisa

I baptize Yusuf, Nisa

I baptize Yusuf and Nisa

(P-3) Hangu, rongu, tolu, aopo, alima, aono, papitu

One, two, three, four, five, six, seven

(P-4) kapituna natuapi ahe einai pade watu

Seventh hard this iron than stone

In the seventh, though iron is harder than stone

(P-5) lako tanoana ana kami kemiei

Head children we here

Our children's head will be harder

Guided by the concept of Morris' semiotics, it can be described by the following picture.

\section{$\underline{\text { Preceeding semiosis }}$}

Acknowledging the text of Gane in Polinaki

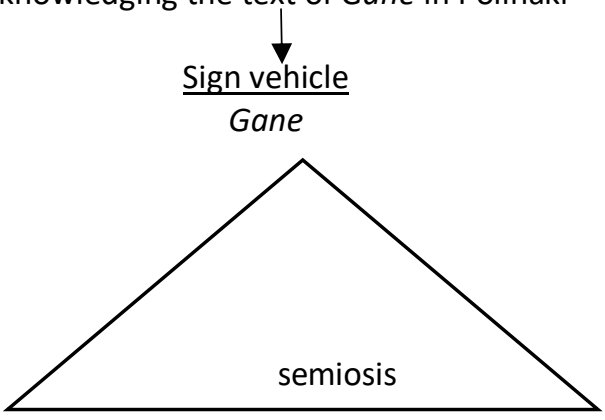

Designatum \& Denotatum

Spoken text functioning as pray or mantra

Gane is spoken in every

God, the spirit of the ancestors and nature are conceptualized in Kulawi society

pic. 2: Depiction of Morris' semiotic on Gane

Behavior

mony $\underline{\text { Interpreter } \rightarrow \text { Interpretant }}$ Kulawi people Sacred text for calling the spirit 
Morris' Semiotic in Religion Perception and Conception in Gane of Polinaki Traditional Wedding Ritual in Ethnic Kulawi, Indah Lestari, Burhanuddin Arafah, Harlinah Sahib, Mustafa Makka

In this dimension, Gane as the sign vehicle is created by its forms, structure, and function. Based on observations and findings in the field, the form of a sign on Gane read in the Polinaki procession is a text spoken without being sung by a Topogane. This sign in Gane is a form of mantra that calls on the spirits to come to witness, give blessing, and keep the ceremony going well without any constraints. follows:

By the structure, Gane consists of linguistic structure derived from Kulawi language as

a. The sound units, the phoneme used in Gane is derived from the phoneme used by Kulawi language consisting of six vowel phonemes, namely / i /, / u /, / e /, / o /, / / /, / a / and

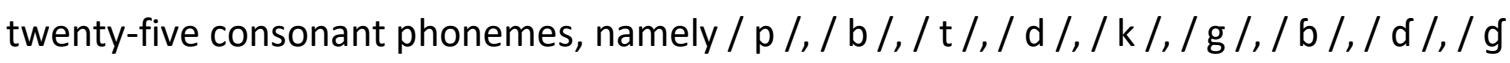

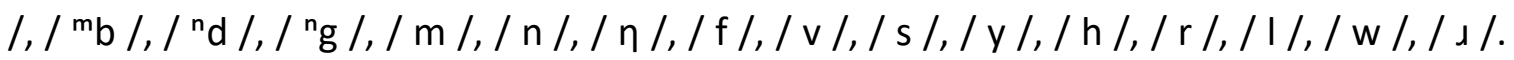
Gane is not marked with vowels in the initial position of the word.

b. By the word, Gane's text consists of syllables formed of a consonant and a vowel (KV), like words ta-na, la-ngi, to-no.

c. By the phrase, Gane text consist of: nominal phrases (FN), such as karampue tana 'ruler of the earth' which refers to actors with a noun + noun $(N+N)$ structure.

d. By the clause, the clause patterns used is subject-predicate (S-P) such as natuapi ahe einai pade watu.

e. The modus used in Gane is declarative

f. By the line relationships, it is characterized by the use of the same words as in (P-1).

The fragments of (P-1) and (P-5) indicate the functions of the Gane speech. In the fragment (P-1) Karampue mata eo, karampue mata wula, 'the lord of sun, the lord of moon', the Gane is functioning as a calling for the spirit exist. When this fragment is being spoken, then all those who had gathered began to approach and close the ranks. In the fragment ( $P$ 5) lako tanoana ana kami kemiei, "Our children's head will be harder, the Gane is functioning as hope, request, and plea, even though it was spoken in declarative modus of sentence.

In semantic dimension, the objects focused are the designatum and the denotatum. Designatum means the concept referred by the sign, while denotatum means the existence of the object referred. As Morris explained, what is referred to actually exists as referred to the object of reference is a denotatum (Cherwitz, 2009). Everything has the concept, but not everything exists in real. For Gane, it has its existence in the form of spoken speech which can be heard and spoken in traditional life cycle ceremony and ritual in everyday life of society, especially in Central Sulawesi. Thus, it has designatum and denotatum.

In semantic dimension, the meaning of Gane is derived from its syntactic dimension. The meaning of the sign found in Gane can be known by combining metasemiotic and semantic theories. The meaning of the sign in Gane can be known to analyze the verbal marks found in Gane text. In the fragment (P-1) Karampu e mata eo, karampu e mata wula, "the lord of sun, the lord of moon", which is then continued on the fragment (P-2) Kunuju I Yusuf, I Nisa, " I baptize Yusuf and Nisa" shows a notification to the spirit of an action that will be performed. This is characterized by the use of declarative mode on sentences that also indicate a permit application. Using the particle 'e' in Karampue, 'the Lord' shows a form of reverence for the spirits of ancestors and spirits of nature. In addition, Gane's readings in loud and clear manner also show the importance of the spirits to be present in this procession. 
Fragment (P-4) and (P-5) in Gane above, although the Topogane reading is in declarative mode, the meaning of his reading shows the needs, desires, hopes, and requests of the Topogane who represented Kulawi people who also performed the ceremony to the spirit in order to give strength to the bride and groom in the face of all the household problems they will live with. In this fragment, the Topogane casts iron and stone as both hard objects, (P-4) ... natuapi ahe einai pade watu", "though iron is harder than stone", which is expected that these two brides have a hard character over iron let alone the stone, as in the fragment (P-5) lako tanoana ana kami kemiei, 'Our children's head will be harder".

Based on the structure and the meaning, it is obtained what value carried by Gane by its users, namely Kulawi society. For To Kulawi, Kulawi people, Gane is spoken in every traditional life cycle ceremony. Each ceremony has its own Gane and the Topogane reads it contextually. Gane is one of the important components in the ritual carried in traditional life cycle ceremony besides Raego, Mboha, Meaveli, and Ombo. It has its own structure and rules. People believed that it cannot be read recklessly for it has sacred meaning.

Based on the interview with an informant in Kulawi, not every people can be a Topogane. To be a Topogane, one must be special. It has to be native, a direct decent of the former Topogane or the one who designated by the former Topogane or Totua Ngata, the head of customs in the village. Also, not every people can have Gane to be read in their ceremony. They must be a Mahardika, nobility or descendant of nobility. If the rules are violated, Kulawi believed that disasters and misfortune would struck the community or those who were read out Gane.

Observed from those reasons, people in Kulawi cannot underestimate or rule out the role of Gane in daily life. Every misfortune and disasters happen after Gane is spoken out is believed because God and the spirit of the ancestors and nature are unhappy and the mistake of reading the Gane is one of the reasons. That is why people in Kulawi are very careful in choosing who will be the Topogane.

\section{Religion Conception in Kulawi Society through Gane}

As one of the forms of communication to spiritual things, Gane can be use as one of the doors to explore and to understand what concept of religion the users have.

\section{Conceptualization of the Existence of God}

In the ethnic Kulawi conceptualization, God is understood as the Lord of the Universe, as can be seen in fragments 1) Karampu e tana '; 2) Karampu e langi '. The lord of the earth and the lord of the heaven. This shows that in the ethnic Kulawi's perspective, God is the owner of the universe and all of its contents that cover the earth and the sky (heaven). The Kulawi word or term that reveals the ethnic Kulawi's conceptualization of the existence of God as the ruler of the universe is Karampua. It implies that, in the ethnic Kulawi conceptualization, the range of God's power as the ruler of the universe covers the heavens and the earth with everything in it, including humans as His creatures.

The next fragment, 3) Kamaimo kita mompetiro, let's all look from the top down imply that in the ethnic Kulawi, conceptualization God is understood as the highest being and human is down below the supervision of God because He is the owner and ruler of the universe. This is indicated by the adverb of locative markers mompetiro, from top to down. 
Starting from that understanding, every effort made in the context of his life in the world will achieve success if God's blessing. This means that humans may try their best to work, but God determines his success because $\mathrm{He}$ is the source of moral strength who is the ruler of the universe. In accordance with the essence of the message contained in the fragment, the Kulawi ethnic group is reminded to always involve God in the context of their everyday life.

The manifestation of worship to God as the ruler of the universe, apart from being reflected in the choice of words, is also represented in the way of expressing his language. The variety of languages used in Gane has a distinctive structure, function, and meaning as a distinction between the various languages commonly used by the Kulawi ethnic group in the context of everyday life. The uniqueness as Gane's distinction can be seen from the use of various formal and standard ritual languages. The various ritual languages used in Gane are neatly woven together in a unified structure and texture with a framework of meaning that supports and emphasizes each other. As seen in the fragments 7), Nemo rapakavana, 8), Nemo rapaka nanggo and 9) Nemo rapaka vuyu.

Considering that Gane functions as a medium of communication with God as the ruler of the universe, the language order used is aesthetically structured by utilizing a variety of language instruments. The variety of literary languages used not only contains the beauty of form when viewed, but also invites sensory enjoyment when listened to. The reality of the use of various literary languages in Gane, apart from being intended to create a musical effect and support fluency in speech, also aims to make the prayers they pray to God sound clear without appearing arrogant and pushy. As seen in the fragments 7), Nemo rapakavana, 8), Nemo rapaka nanggo and 9) Nemo rapaka vuyu.

It is also as a symbol that they position themselves as creatures who submit to God's decisions. Politeness of language is part of Gane's ritual piety which implies that God has a higher power structure than humans. As seen in the fragment 6) Ala mosirata mboi kita nggapurina, so we can meet again. The fragment implies that if the Lord does not grant their pray, they will not survive.

In addition to being expressed verbally by using various literary languages with demands for certain nonverbal behavior, the manifestation of worship to God is also manifested through offerings, as observed in the fragment 10) Sipuramo kandea miu mpengana.

\section{Conceptualization of the Ancestral Spirit Existence}

As mentioned earlier, apart from revealing the existence of God as the ruler of the universe, Gane also implies the ethnic Kulawi's conceptualization of the existence of ancestral spirits as the most prominent dimension of meaning. Judging from the hierarchical structure of power, the existence of ancestral spirits is not in the same position and equal to God. In the ethnic Kulawi's conceptualization, the ancestral spirit is understood as an intermediary for prayer requests to God as the ruler of the universe. This conceptualization affirms that the Kulawi ethnic group does not worship ancestral spirits, but respects ancestral spirits in relation to its role as an intermediary for prayer requests to God.

As seen in the fragment of Ana ada mpae topoviata, Please all of you, speakers invite the spirits of the ancestors to be involved in helping pray to God with the hope that the prayers spoken will be faster and have the potential to be answered with the help of the spirits of the ancestors who prayed. This is also supported by the next fragment, Manggelo anu nipoviakarapa kajadi, pray for our efforts to succeed. 


\section{Conceptualization of the Spirit Nature's Existence}

As mentioned earlier, in the ethnic Kulawi's conceptualization, the natural spirit is understood as a source of moral and spiritual strength that determines the existence, survival and continuity of life as a human being and a member of society, besides God and the spirit of nature. However, the Kulawi ethnic group understood the existence of the natural spirit not as an independent spiritual force, but seen from a relationship with God as the creator of the universe. In the ethnic Kulawi's conceptualization, natural spirits are understood as creatures created by God who inhabit the other side of the world of human society. The natural spirit is assigned by God to wait and protect the natural environment so that it is sustainable and is not used by humans irregularly.

Applying the semiotic analysis developed by Charles Morris, it was found that in the syntax dimension of the Gane text is a literary-style discourse having a distinctive and orderly structure supported by formal structure and narrative structure. In semantic dimensions, Gane carries out various functions that are then studied in search of the meaning of the Gane. Gane's text is loaded with philosophical meaning as a guide for ethnic Kulawi in making pilgrimages to his life as a human being and member of society. Last, in terms of pragmatic dimensions can be seen what impact Gane brings with regard to the religious aspects of Kulawi society. From the results presented it is seen that the perception and conception of Kulawi community religion related to religion is related to God, ancestral spirit, and spirit of nature.

\section{Conclusion}

Observed from the structure and the meaning, it can be seen that Gane is not only a small part of ritual in Polinaki procession, but also an important medium to communicate with God and spirits. From the structure which is observed in syntactic dimension, Gane contained a certain formula from the sound units, words, phrases, and the relationship between the lines. As for the meaning in semantic dimension, Gane is a medium to dispense the hope of To Kulawi. Those results are then used to find out how To Kulawi conceptualizes and perceives religion regarding Gods and spirits.

Moreover, Gane is a short text. It is inevitable that it contains limited fragments to be the data to observe the view of life of To Kulawi. Hopefully the further research can provide deeper results by observing other ritual speeches of Kulawi such as Meaveli, Raego, or Mboha.

\section{References}

Akhmar, A. M., Arafah, B., \& Pardiman, W. (2017). Strategi Budaya Orang Bugis Pagatan dalam Menjaga Identitas Ke-Bugis-an dalam Masyarakat Multikultur. Kapata Arkeologi, 13(1), 73. https://doi.org/10.24832/kapata.v13i1.392

Arafah, B., \& Kaharuddin, (2019). The Representation of Complaints in English and Indonesian Discourses. Opción, 35, 501-517. https://www.researchgate.net/ publication/339160079. The_Representation_of_Complaints_in_English_and Indonesian_Discourses.

Arafah, B. \& Kaharuddin. (2019). The Idol: A Model for Incorporating Literature in ELT. KnE Social Sciences, 43-59. https://knepublishing.com/index.php/KneSocial/article/view/4829.

Arafah, B., Thayyib, M., Kaharuddin, \& Sahib, H. (2020). An Anthropolongical Linguistic Study on Maccera' Bulung Ritual. Opcion, 36 (special Edition 27), 1592-1606. https://scholar.google.co.id/citations?user=xqRE39AAAAAJ\&hl=en. 
Morris' Semiotic in Religion Perception and Conception in Gane of Polinaki Traditional Wedding Ritual in Ethnic Kulawi, Indah Lestari, Burhanuddin Arafah, Harlinah Sahib, Mustafa Makka

Arafah, B., Jamulia. J., \& Kaharuddin. (2020). The Speaking People of South Halmahera Languages: A study on Cultural Relationship. Journal of Talent Development and Excellence, 12(3s), 1331-1340. https://www.researchgate.net/publication/341407846 The_Speaking_People_of_South_Halmahera_Languages_A_study_on_Cultural_Relati onship.

Arafah, B., \& Hasyim, M. (2019). Linguistic Functions of Emoji in Social Media Communication. Opcion, 35(SpecialEdition24), 558-574. https://www.researchgate.net/profile/HasyimMuhammad/publication/338286019_L inguistic_functions_of_emoji_in_social_media_communication/links/5e0bf13f92851 c8364a923b6/Linguistic-functions-of-emoji-in-social-media-communication.pdf.

Cherwitz, Richard A. (2009). Charles Morris' Conception of Semiotic: Implications for Rhetorical Criticism. Community Quarterly. https://www.tandfonline.com/doi/abs/ 10.1080/01463378109369408?journalCode=rcqu20.

Lewis, Phillip. (2015). Qualitative Inquiry and Research Design. New York: Macmillan.

Merrell, F., Queiroz, J., Merrell, F., \& NADIN, M. (2006). Semiosis and Pragmatism: Toward a Dynamic Concept of Meaning. Sign Systems Studies, 34(1), 37-65. http://scholar.google.com/scholar?hl=en\&btnG=Search\&q=intitle:Pragmatics+in+the +Semiotic+Frame\#1

Nitayadnya. (2014). The Meaning of Culture Symbol In Gane, Rego Mate, Meaveli, Mboha, and Ombo on Death Ritual of Kulawi Ethnics. Totobuang: Jurnal IImiah Kebahasaan dan Kesastraan, Volume 2, Nomor 2 Desember 2014, Kantor Bahasa Provinsi Maluku Utara.https://www.google.com/search?client=firefox-b-e\&q=Jurnal+Ilmiah+ Kebahasaan+dan+Kesastraan\%2C+Volume+2\%2C+Nomor+2+Desember+2014\%2C+Ka ntor+Bahasa+Provinsi+Maluku+Utara.+.

Ola, S.S (2012). Makna dan Tuturan Ritual Lewak Tapo Pada Kelompok Etnik Lamaholot di Pulau Adonara, Kabupaten Flores Timur. Jurnal Humaniora, Vol.21. No 3 Oktober 2009, pp 301-309. https://jurnal.ugm.ac.id/jurnal-humaniora/article/view/974.

Petrilli, S. (2004, January). From Pragmatic Philosophy to Behavioral Semiotics:Charles W. Morris after Charles S. Peirce. Semiotica 2004(148), pp. 277-315. https://www.researchgate.net/publication/242156824_From_pragmatic_philosophy _to_behavioral_semiotics_Charles_W_Morris_after_Charles_S_Peirce.

Rifa'in M. R, S. B., Pa, M. T. Bin, \& Samah, R. (2018). Analysis of the language style of amr in the context of hajj in surah al-baqarah. GEMA Online Journal of Language Studies, 18(2), 235-254. https://doi.org/10.17576/gema-2018-1802-16.

Sahib.H ., Arafah.B., Manda, M.L., \& Machmoed.H. (2017)Entextualization and Genre Transformation of Kajang Death Ritual Speech. International Journal of Science and Research (IJSR), 6(1), 232-236. https://doi.org/10.21275/art20163925.

Sahib, H., Rahman, F., Duli, A., \& Asba, A. R. (2019). Customary Forest Conservation through Informal Knowledge System of Ammatowa Community. IOP Conference Series: Earth and Environmental Science, 270(1). https://doi.org/10.1088/1755-.

Thomas, D. R. (2006). A General Inductive Approach for Analyzing Qualitative Evaluation Data. American Journal of Evaluation, 27(2), 237-246. https://doi.org/10.1177/1098214005283748.

Старцев, Д. А., Старцев, А., \& Нотний, Д. А. (2020). Нотний текст в аспекті семіотичної теорії Чарльза Морріса. 200-212. https://doi.org/10.34064/khnum1-5613. 